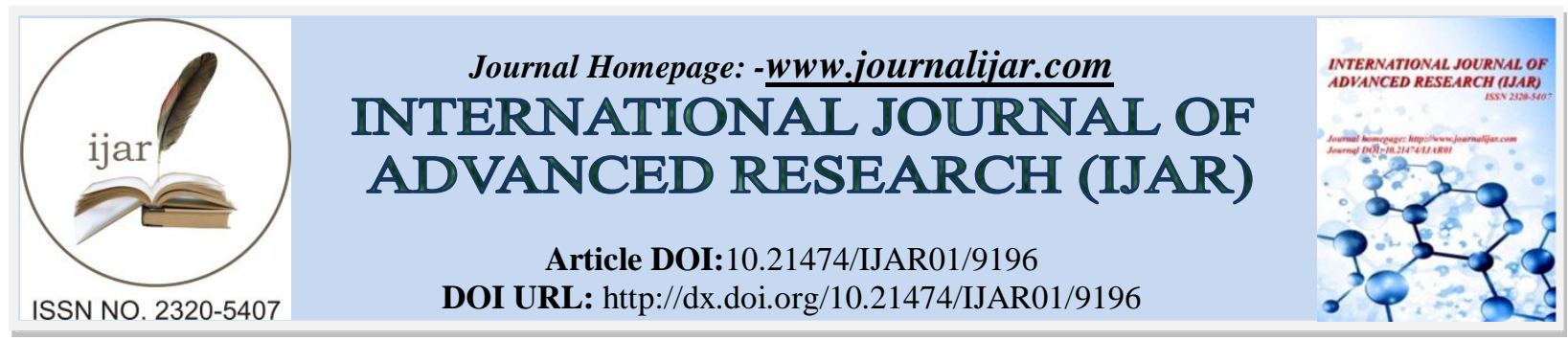

RESEARCH ARTICLE

\title{
ESTIMATION OF SERUM COPPER, ZINC AND COPPER ZINC RATIO IN UNTREATED PULMONARY TUBERCULOSIS PATIENTS IN COMPARISION TO HEALTHY SUBJECTS.
}

\author{
Dr. Varsha Chowdhry, Dr. Balram Chowdhry and Dr. G.G Kaushik.
}

MD (Assistant Professor), MD (Ex.Sr. Professor \& HOD Presently working as sr. consultantant Gheesibai Mittal Hospital and research centre), MD (Sr Professor \& HOD)Department of BiochemistryJ.L.N. Medical College \& Hospital, Ajmer, Rajasthan, 305001 INDIA.

\section{Manuscript Info}

Manuscript History

Received: 02 April 2019

Final Accepted: 04 May 2019

Published: June 2019

Key words:-

Pulmonary Tuberculosis, Copper, Zinc,

$\mathrm{Cu} / \mathrm{Zn}$ Ratio, Total Protein, Albumin.

\begin{abstract}
Background: Several independent studies have shown the role of micronutrients like copper and zinc in controlling the severity of pulmonary tuberculosis.Tuberculosis is an important global health problem which is declared as global emergency by WorldHealth Organization (WHO) in 1993. The basic problem is in early diagnosis of the disease and neglecting the role of essential micro nutritrient like copper, Zinc.

Aim: Aim of the present study was to Estimation and correlate fasting serum Zinc,Copper, total protein and albumin in newly detected untreated pulmonary tuberculosis patients of age group from 11 years to 45 years of either sex. To compare the serum copper, zinc level, $\mathrm{cu} / \mathrm{Zn}$ ratio, total protein and albumin in newly detected untreated pulmonary tuberculosis patients with healthy volunters.

Materials and method: The study included 50 newly detected sputum smear positive, untreated pulmonary tuberculosis patients and 50 healthy controls. Serum Copper, Zinc, Total Protein and Albumin were estimated in these subject.Present study was conducted in JLN medical college department of Biochemistry.

Results and conclusion: The copper level and $\mathrm{Cu} / \mathrm{Zn}$ ratio was significantly increased in untreated pulmonary tuberculosis patients with $\mathrm{p}$ value of $<0.0001$. The zinc levels decreased with decrease in total protein and albumin levels when compared to normal healthy group with a significant $\mathrm{p}$ value of $<0.001$. Hence the early and effective diagnosis of tuberculosis in the study group was influenced by factors such as increase copper, decrease zinc levels and increased copper zinc ratio
\end{abstract}

Copy Right, IJAR, 2019,. All rights reserved.

\section{Introduction:-}

Tuberculosis (TB) is an important global health problem. It has more impact on developing and under developing countries. The Impact of tuberculosis can be seen by the fact that in 1993, The World Health Organization (WHO) declared tuberculosis is a global emergency. WHO estimated that tuberculosis infects about $1 / 3^{\text {rd }}$ of world's population. Every year, 8 million people contact tuberculosis of which $95 \%$ are in the developing world [1].

Corresponding Author:-Dr Varsha Chowdhry.

Address:-MD (Assistant Professor), MD (Ex.Sr. Professor \& HOD pediatrics Sr. CONSULTANT MITTAL HOSPITAL), MD (Sr Professor \& HOD)Department of Biochemistry. Medical College \& Hospital, Ajmer, Rajasthan, 305001 INDIA. 
It is estimated that between 2002 and 2020, tuberculosis will be affect nearly 1 million people and 35 million will be die of tuberculosis, if it is not controlled. Therefore control of Tuberculosis and better chemotherapy is still a challenge in the management of tuberculosis infection in the $21^{\text {st }}$ century. The basic problem arises in early diagnosis of the disease and by the time of the patient comes to the treatment, the disease is already fully established [2].

Many elements present in minute quantities in man are essential nutrition. Their presence was long overlooked and it has been only in recent years that analytical techniques capable of measuring such trace levels were developed. These trace elements perform functions in dispensable to the maintenance and growth of tissues. The trace metals have been examined critically as a potential key factor in various diseases. The two important micro nutrients, namely Zinc and Copper play distinctive role in the pathphysiological process of Tuberculosis [3,4,5].

Several studies have been done to study the influence of these individual risk factors on the pathophysiology of tuberculosis. However, very few studies have been done to study the correlation between these risk factors in pulmonary tuberculosis. This study for serum copper, zinc levels in patients of tuberculosis is being undertaken to see if changes of these parameters might be helpful in the early diagnosis of the disease leading to decreased morbidity and mortality by early treatment.

\section{Aim and objective:}

The objective of Present study is to study the importance of various micronutrients in early diagnosis and treatment of pulmonary tuberculosis patients of age group from 11 years to 45 years of either sex

\section{Materials and Methods:-}

The present study was conducted on 50 patients attending the Medical OPD and Radio Immuno Assay (RIA) Laboratory of the Biochemistry Department of JawaharLal Nehru Medical College \& attached group of Hospital, Ajmer. The results of patients were compared with 50 healthy control subjects of either sex of similar age group (1145 years). Serum Copper, Zinc,Total Protein, and Albumin were estimated in their subjects. $6 \mathrm{ml}$ of blood was collected from an antecubital vein from all the subjects in tubes containing EDTA (for hematologic studies); Blood samples were centrifuged within 2 hours of collection. After centrifugation, serum and plasma were separated and aliquots were stored at $-70^{\circ} \mathrm{C}$ until assayed. Samples were thawed at room temperature, vortexed and centrifuged before analysis.

Serum copper and zinc was estimated by colorimetric method using RA-50 semi auto analyzer. At $\mathrm{pH} 4.7$, copper which is bound to cerulopalsmin, release by reducing agent. It can react with a specific color reagents 3.5-Do-BrPAESA-4 (3,5-dibromo-2 pyridylazo-) N-Ethyl-N-(3-Sulphopropyl) aniline to form a stable, colored chelate. The intensity of the color is directly proportional to the amount of copper in the sample.

Zinc present in the sample is chelated by 5-Br-PAPS (2-(5-Bromo-2-pyridylazo) -5-(N-propyl- N-sulpho propyl amino) - phenol in the reagent. The formation of this complex is measured at the wavelength of $560 \mathrm{~nm}$.

T Protein and Albumin was estimated using the Randox, Daytona auto analyzer. T protein was estimated by Biuret method, end point using Erba Mannheim kit FBCER0057. Albumin was estimated by Bromocresol green method using Randox kit AB3800 in. Statistical analysis was done by Student t test (two tailed, independent) to find the significance between cases and control

\section{Results:-}

The present study was conducted on 50 untreated pulmonary tuberculosis patients and 50 healthy controls. The cases and controls were age and sex matched. The age group was between 11-45 years. The mean age in tuberculosis patients was $20.4 \pm 5.85$ years and in controls, it was $21 \pm 5.48$. Among 50 patients 28 were men and 12 were women. The total protein, albumin A/G ratio in patients was $7.27 \pm 0.92 \mathrm{~g} / \mathrm{dl}, 3.61 \pm 0.17 \mathrm{~g} / \mathrm{dl}$ and $1.04 \pm 0.26$ $\mathrm{g} / \mathrm{dl}$ respectively. In controls, it was $8.47 \pm 0.43 \mathrm{~g} / \mathrm{dl}, 4.43 \pm 0.42 \mathrm{~g} / \mathrm{dl}$ and $1.12 \pm 0.21 \mathrm{~g} / \mathrm{dl}$ respectively.

There was a significant decrease in the mean total protein and albumin levels values in tuberculosis patients when compared to the control group $(\mathrm{p}<0.001)$. 
There was significant increase in serum copper levels in pulmonary tuberculosis patients when compared to the control group $(221.93 \pm 64.92 \mu \mathrm{g} / \mathrm{dl}$ and $137.83 \pm 26.71 \mu \mathrm{g} / \mathrm{dl}$ respectively). There was significant decrease in $\mathrm{Zn}$ in pulmonary tuberculosis patients when compared to controls, $(170.97+34.99 \mu \mathrm{g} / \mathrm{dl}$ and $207.7 \pm 38.37 \mu \mathrm{g} / \mathrm{dl}$ respectively). The $\mathrm{cu} / \mathrm{Zn}$ ratio was significantly higher in patients than control $(1.35 \pm 0.46$ and $0.69 \pm 0.19$ respectively).

Mean and SD of Serum $\mathrm{Cu}, \mathrm{Zn}, \mathrm{Cu} / \mathrm{Zn}$ Ratio in the study group was as per Table -1 . Correlation between the various parameters was as per Table-2. Copper was positively correlated with $\mathrm{Cu} / \mathrm{Zn}$ ratio $(\mathrm{p}<0.05)$. Zinc was negatively correlated with $\mathrm{Cu} / \mathrm{Zn}$ ratio $(\mathrm{p}<0.05)$.

Table 1:-Mean and SD of Serum $\mathrm{Cu}, \mathrm{Zn}$ and $\mathrm{Cu} / \mathrm{Zn}$ Ratio in the study group.

\begin{tabular}{|l|c|c|c|c|}
\hline & Mean + SD & \multirow{2}{*}{ t-value } & p-value \\
\cline { 2 - 3 } & Tuberculosis patients & Controls & & $<0.0001$ \\
\hline Copper & $221.93 \pm 64.92$ & $137.83 \pm 26.71$ & 7.48 & $<0.0001$ \\
\hline Zinc & $170.97 \pm 34.99$ & $207.71 \pm 38.37$ & -4.42 & $<0.0001$ \\
\hline Cu/Zn Ratio & $1.35 \pm 0.46$ & $0.69 \pm 0.19$ & 8.19 & $<0.0001$ \\
\hline T. Protein & $7.27 \pm 0.92$ & $8.47 \pm 0.43$ & -7.38 & $<0.0001$ \\
\hline Albumin & $3.61 \pm 0.17$ & $4.43 \pm 0.42$ & -11.18 & \\
\hline
\end{tabular}

Table 2 :-Correlation between the various parameters.

\begin{tabular}{|l|c|c|c|}
\hline & Copper & Zinc & Cu/Zn Ratio \\
\hline Copper & 1.000 & -0.037 & $0.833^{*}$ \\
\hline Zinc & & 1.000 & $-0.554^{*}$ \\
\hline $\mathrm{Cu} /$ Zn Ratio & & 1.000 \\
\hline
\end{tabular}

$* \mathrm{p}$ value $<0.05$ (Statistically significant)

\section{Discussion:-}

The present study was conducted on 50 untreated pulmonary tuberculosis patients and 50 healthy controls. Among 50 patients 30 were men and 20 were women.

Total protein, albumin was done to rule out hypoproteinemia, to rule out mal nutrition (i.e. deficiency due to decrease carrier proteins as occurring in malnutrition) or acute mal nutrition deficiency (i.e in spite of normal protein level).Both in patients and controls, the total protein level and albumin levels was within normal range and the criteria to rule out hypoproteinemia was met. But the levels were decreased in patients when compared with controls and it was statistically significant ( $\mathrm{p}<0.001$ for total protein and $\mathrm{p}<0.0001$ for albumin), there was no significant difference in $\mathrm{A} / \mathrm{G}$ ratio.

Our findings are comparable with the study done by Ramakrishna L et al., he showed relation in the concentration of plasma albumin and zinc was significant in pulmonary tuberculosis patients irrespective of HIV co-infection [6]. K. Heran et al 2015 proved that micronutrients copper and zinc have a role in developing nutritional immunity in the host, he also said that there is litte doubt that the understanding of icrobes and host regulate metabolic homeostasis, thus leading to improve outcome of treatment of pulmonary tuberculosis.

Muthuraj M, et al., in their study showed that significant decrease in serum albumin as, patients had nutritional factors enteropathy and acute phase reactant proteins. The hepatic synthesis of acute phase reactant proteins is induced by cytokines such as interleukin 6 and tumor necrosis factor, which inhibit the production of serum albumin and cause dramatic shifts in the plasma concentration of certain essential micro nutrients and albumin $[7,8,9,10]$.

In the present study there was significant increase in copper levels in pulmonary tuberculosis (TB) patients than in controls as thre receptors were loaded by raised copper levels. The mean copper level I PTB was $221.93 \pm 64.92$ $\mu \mathrm{g} / \mathrm{dl}$ and in the controls it was $137.83 \pm 26.71 \mu \mathrm{g} / \mathrm{dl}(\mathrm{P}<0.0001)$. Our findings on copper levels were comparable with previous study done by the Ciftici T.U. et al., who have found that there is significant increase in serum, copper levels in tuberculosis than in normal subjects [11]. 
Reza B.M et al., have also shown in their study that serum copper levels were significantly higher in patients with active pulmonary tuberculosis than in healthy control [12]. Another study reveals that rise in serum copper level during infection or inflammatory stress conditions was due to the release of IL-1 [13].

In the present study, there was significant decrease in Serum Zinc levels in the patients than in controls groups. The mean serum zinc levels in patients and controls was $170.97 \pm 34.99$ and $207.71 \pm 38.37$ respectively $(\mathrm{p}<0.0001)$. Oluboya $\mathrm{P} \mathrm{O}$ et al., in their study have pointed that pulmonary TB affects metabolism of trace elements like any other infection diseases. In their study, there was fall in plasma zinc level in the cases and was found to be statistically significant [14]. Muthuraj M et al., in their study found significantly decrease in serum zinc in patients with PTB, irrespective of their HIV status. The possible for the low serum Zinc were considered to be nutritional factors Enteropathy and acute phase reactant proteins $[7,8]$.

Low Zinc status in patients with inflammatory disease has been attributed to less of Zinc form catabolized tissue and increased urinary excretion of $\mathrm{Zn}$ subsequent to its mobilization by IL-1. Low zinc are likely the result of re distribution of Zinc from plasma to other or reduction of hepatic production of the zinc carrier protein $\alpha-2$ macro globulin and of a rise in the production of metallothionein [15].

In our study, copper / Zinc $(\mathrm{Cu} / \mathrm{Zn})$ ratio was calculated and we found that there was significant increase in $\mathrm{Cu} / \mathrm{Zn}$ ratio in tuberculosis patients than in the controls. Then mean $\mathrm{Cu} / \mathrm{Zn}$ ratio in PTB patients and controls was $1.35 \pm 0.460 .69 \pm 0.19$ respectively, $(\mathrm{p}<0.0001)$.

Our findings of $\mathrm{Cu} / \mathrm{Zn}$ ratio were comparable with study done by the Ciftici T.U et al., who have found an initial increase in $\mathrm{Cu} / \mathrm{Zn}$ ratio in patients prior to treatment an on follow up of same group after 2 months with treatment there was a significant decrease in $\mathrm{Cu} / \mathrm{Zn}$ ratio and thus concluded saying that serum $\mathrm{Zn}$ level and $\mathrm{Cu} / \mathrm{Zn}$ ratio could serve as a diagnostic tool to assess the beneficial effects of antituberculosis therapy [11].

Mohan $\mathrm{G}$ et al., observed an initial significant increase in $\mathrm{Cu} / \mathrm{Zn}$ ratio prior to treatment and there was significant decrease after anti tubercular therapy and have hypothecate that $\mathrm{Cu} / \mathrm{Zn}$ ratio can be used as an important laboratory marker for the diagnosis of tuberculosis [16]. Reza B.M., et al., in their study on children with PTB found a higher $\mathrm{Cu} / \mathrm{Zn}$ ratio in patients than in controls, which was in agreement with our study [12].

\section{Conclusion:-}

Based on the results of present study and data available from literature it can be concluded that dietary deficiency of trace elements like copper and zinc have been associated with defective function of immune mechanisms in humans and hence this imbalance in this elements may be associated in the pathophysiological of infectious diseases like PTB. Our study showed in increased $\mathrm{Cu}$ levels and $\mathrm{Cu} / \mathrm{Zn}$ ratio reflecting the ongoing inflammatory process. Decreased level of $\mathrm{Zn}$ could be due to pre-existing malnutrition and increased usage of $\mathrm{Zn}$ by the tuberculosis bacteria itself. Thus these parameters directly reflect the pathophysiological state of the disease process. From the results of present study, it can be concluded that estimation of serum copper, Zinc, $\mathrm{Cu} / \mathrm{Zn}$ ratio can have an auxiliary values in the early diagnosis and in monitoring the prognosis of subjects with pulmonary tuberculosis. On the other hand we can only speculate as to whether the serum copper Zinc and $\mathrm{Cu} / \mathrm{Zn}$ ratio could be serve as a diagnostic toll and to access the beneficial effects of anti tuberculosis therapy.

\section{Acknowledgement:}

I am highly indebted to the staff \& my colleagues who helped me to accomplish my project.

\section{Conflict of Interest:}

None declared.

\section{Research funding:}

None declared. 


\section{References:-}

1. Mohan G, Kulshreshtha S, Sharma P. Zinc and Copper in Indian patients of tuberculosis. Biological trace elements research, 2006; 111:63-69.

2. Bodgen J N, Lintz D I, Joselow M M. Effects of Pulmonary Tuberculosis on Blood Concentration of Copper and Zinc. A J Clin Pathol., 1977; 251-256.

3. Oyama T, Matsuno K, Kawamoto T. fficiency of Serum Copper / Zinc Ratio for differential diagnosis of Patients with and without Lung Cancer. Bilol Trace Elements Res., 1994; 42:115-127.

4. McMurry D N, Bartow R A, Mintzer C L, Frontera E H. Micronutrient Status and Immune Function in Tuberculosis. Ann Ny Acad Sci., 1995; 38:287-292.

5. Bell L, Bhat V, George G, A wotedy A A, Gqaza B. Sluggish glucose tolerance in tuberculosis patients. SAMI, 2007; 97:374-377.

6. Ramakrishnan K, Shenbagarathi R, Kavitha K, et al., Serum Zinc and albu, in Levels in pulmonary tuberculosis patients with an without HW. Jpn J Infect Dis., 2008; 61:202-204.

7. Muthuraj M, Kamatchiyammal S, Usharani B, Manupriya S, Ayyappan ARN, Divyalakshmi K, Serum Zinc, Calcium and Albumin Leels in pulmonary Tuberculosis patients co-injected with HIV. Global Journal of Biotechnology and Biochemistry, 2010; 5(1):27-35.

8. Karyadi E, West CE, Schultink W, et al., A double blient placebo-controlled study of vitamin - A and Zinc supplementation in persons with tuberculosis in Indonesia-effects on clinical response and nutritional status. Am J Clin Nutro., 200;75:720-727.

9. Xing Z, Gauldie J, Cox Get et al., IL-6 is an anti inflammatory cytokine required for controlling local or systemic

acute

10. inflammatory responses. J Clin Invest., 1998; 101: 311-320.

11. Gabay $\mathrm{C}$ and Kushner I. Acute phase protein and other systemic responses to inflammation. N England J Med., 1999; 340:448-454.

12. Ciftci T U, Cifti, Yis O, Guney Y, Bilgiham A, Ogreten Soy M. Changes in Serum Selenium, Copper, Zinc levels and $\mathrm{Cu} / \mathrm{Zn}$ Ratio in patients with pulmonary tuberculosis during therapy. Biol Trace Elem Res., 2003; 95:65-71.

13. Reza B M, Soheila K, Reza M A, et al., Evaluation of Copper, Zinc and Copper/Zinc ratio in the serum of pulmonary tuberculosis children. Pediatric on Call, 2007; 4:1-6.

14. Parker M M, Humoller F L, Jahler D J. Determination of Copper and Zinc in Biological Material. Clinical Chemistry, 1967; 13(1): 40-48.

15. Olyboya P O, Erasmus R T. The Significance of Glucose Intolerance in Pulmonary Tuberculosis. Tubercle, 1990; 71:135.

16. Dececi F, Ilhan N, Plasma Malondialdehyde and serum trace element concentrations in patients with active pulmonary tuberculosis. Biological Trace Element Res., 2003; 95:29-38.

17. Mohan G, Kulshreshtha S, Dayal R, Singh M, Sharma P, Effect of Therapy on Serum Zinc and Copper in Primary Complex of Children. Biological Trace Element Res., 2007, 118:184-190. 